\title{
Advertising and localization
}

\begin{abstract}
Localization and advertising are much more related than usually accepted. In this chapter the concept of localizing a source product will be analyzed not only from a translation but also from business point of view. Both approaches find a specific application in the field of advertising. Concepts and issues on how to appropriate a marketing campaign around a single product are analyzed.
\end{abstract}

\section{Key words}

Cross-cultural - International advertising - localization - standardization - cultural models

\section{Abbreviations}

$\mathrm{B} 2 \mathrm{~B}$ - business to business

EPRG - ethnocentric, polycentric, regiocentric or geocentric

GALA - Globalization and Localization Association

GILT - Globalization, Internationalization, Localization, Translation

HTML - Hypertext Mark-up Language

IDV - Individualism (versus collectivism)

LISA - Localization Industry Standards Association

LTO - Long-Term Orientation

MAS - Masculinity (versus femininity)

PDI - Power Distance Index

ST - source text

UAI - Uncertainty Avoidance Index

$\mathrm{XML}$ - Extensible Mark-up Language 
Localization nowadays is based around strong business models; companies try to use the globalisation era to increase their profits. Such business models are based, to a certain extent, on cultural models.

(Maroto, 2008)

\section{Introduction}

Within translation studies localization takes a peculiar place. The concept still has difficulty in reaching a general understanding, not in the least because it incorporates a fair amount of computing skills, elements from cross-cultural communication, media studies and, above all, it might very well overlap with business objectives. Nevertheless, from a practical point of view, localization could not be more established.

Localization roughly involves three major fields: multilingual translation projects evolving around complex technical texts, software localization and audiovisual localization (subtitling, games...). Localization involves a considerable amount of computing power but it is much more than just applying technical skills and takes elements from cultural studies and marketing strategies as well. In fact, localization is also a business model. Within global marketing, localization is positioned alongside translation, internationalization, globalization and standardization ${ }^{1}$. Key then is to approach the main concepts and convey the reasoning behind them. By doing so, not only will the relationship between localization and translation become clearer, relevant elements of global and corporate economics and the purposes of local marketing become part of the localization story as well.

\section{Laying the scene: localization versus translation}

The major issue in explaining the concept of localization is its relationship with translation. A first step in positioning both concepts in relation to each other is that localization happens at many levels, one of which is translation. What actually constitutes localization is stipulated in the often used definition by LISA ${ }^{2}$, the Localization Industry Standards Association": "Localization involves taking a product and making it linguistically and culturally appropriate to the target locale (country region and language) where it will be used and sold" (Esselink 2000:3). In response to this description, translators often point at the fact that a translation as well includes proper linguistic and cultural transcreation. If not, the translation can hardly satisfy the needs of the client or the expectations of the target audience. The terminological issues involved in describing translation and localization are acknowledged by LISA who clearly state that localization goes beyond translation as it "also involves more than just making the product readily available in the form and language of the target market. It must speak to the target audience, based on its cultural norms and their 
worldview" (LISA 2005:1). For the localization industry, translation is only a part of a localization project and it would typically leave aside most of the core of translation studies as descriptive features of how to translate, in casu localize, appropriately are not taken into account. However, whereas translation studies disseminate the act of translation seemingly endlessly, the analysis of what actually constitutes localization is very practice-oriented. Any definition of translation is not needed here as localization evolves around all the activities in the localization process but translation.

In practice, localization finds itself within a formal framework, which can be referred to as a 'continuum of complex file formats'. On the one end a single translator would be working on a text, aided only by a word processor, dictionaries and term lists, perhaps using a translation memory tool to convert a specific file format back and forth. On the other end are software localization projects, which involve thorough project management, translating software strings, re-engineering the localized application and above all a wide variety of computer programs. Software localization entails translation of software strings, engineering of the software, testing of the localized program and much more. In-between both ends are the very common multilingual projects of technical texts that are contained in complex file formats that require proper project and that involve file management and several people with various responsibilities. Files originate from software package like FrameMaker, InDesign or could be plain HTML, XML or help files. Whether it concerns a software application, an audiovisual product or a multilingual project, localization always happens at three levels: at the translation level, textual material and text strings are translated, which are then reengineered at the technological level. The third level involves the cultural elements, which in itself involves computing skills as well: a localizer has to know which graphical elements, font size and font type are applicable to a specific target locale, but he or she also has to be able to apply the skills appropriately on a technological level, using various applications such as Catalyst, Passolo, Dreamweaver, Photoshop, InDesign, Flash...

Any positioning of localization against translation is aided by the fact that by definition (aiming at the locale) localization aims at the target audience, it aims to domesticate the source product and 'cover' the other-national or global providence. Localization has a clear purpose, which evolves around its functionality in the target market and as such is very skopos-related. According to Maroto localization even constitutes a new approach to skopos theory as it distinguishes between tradition-free products and culture-bound products. This means that "the same product can occupy a completely different space in the perception of consumers in different markets. This perception is "the result of advertising campaigns combined with local attitudes and culture". (Maroto 2005:2-8) The distinction effectively highlights the core dichotomy in marketing: global standardization versus localization. 


\section{Case: a French car aiming for Scandinavia, and beyond}

In the award-winning commercial 'The Sculptor', an Indian man 'sculpts' a car of a local brand into the shape of a Peugeot 206. The commercial, designed by the Milan-based agency Euro RSCG MCM, evolves around a youthful and innovative image and has an important role attributed to joy. Its British equivalent, the 206 commercial, sees a father, driving an old Peugeot, assist his young son in a bank robbery so that he can afford the 206.

A Swedish commercial for the Peugeot series ${ }^{4}$, produced by Morkman, sees the French car fit in the Bilen I Dit Liv campaign ("a car for life"), which could suit target audiences beyond Scandinavia. Plan8, a Stockholm-based media company, commented on the ad that "the best way of thinking through big questions or just how your day has been" is "when you're travelling, listening to your favourite music? Very soothing." (Plan8 2008). The mission of the Swedish campaign of the 307 convertible on the other hand was "to get the target group to start to think about buying a convertible in the middle of the winter in Sweden" (ICOM Europe, no date) Both the Plan8 analysis and the ICOM mission statement are confirmed by Maroto who states that "you need to keep mind that car makers are no longer selling cars, but feelings, emotions" (2008)

Whether the Italian commercial for the Peugeot 207 would take on anywhere else remains to be seen. The typical Italian landscapes and scenery (very 'locale' related) would appeal to Italians and Italy lovers only. Whether the Hungarian Peugeot commercial, with its blunt pseudo-eroticism, would be appropriate for anywhere else, will remain a hypothetical issue.

\section{International territories and global tribes}

There can be no localization without internationalization, sometimes also referred to as 'enabling'. On a formal level, internationalization is "the lead-in activity to localization" (Wright 1998) and entails all required preparations for a product to be localized. The source product has to be able to handle beforehand "multiple languages and cultural conventions without the need for re-design" (Wright 1998). The entire process of internationalization is virtually localizing the product before it is even conceived. An example of unsuccessful internationalization is a software application designed in English and while aiming at the Finnish market, the drop down menu text boxes do not allow for a text swell of about 10 to $15 \%$ (as Finnish is much longer a language than English in character count).

Internationalization can only succeed when country-dependent information or culture-related technical elements are removed from the initial design before the product is brought onto the market. In a representative setting, Smith-Ferrier mentions that "in the .NET Framework 2.0, the list of available cultures is a combination of those cultures known to the .NET Framework plus those known to the operating system. (...) These cultures are fine if the country/language combination that you need is one of the available cultures and if the information for that 
combination is correct for your application. (...) "which is why custom cultures were introduced in the .NET framework 2.0. A custom culture is a culture that is defined by an application developer instead of Microsoft" (Smith-Ferrier 2006:361).

The purpose of internationalization, customized or not, is to prepare a source product that can be localized easily and as such, regrettably or not, well-internationalized software avoids cultural references and stereotypes that may be unacceptable or incomprehensible in target cultures. By staying as neutral as possible fewer issues in the design of the application occur, the source product remains pretty much the same in all its local versions and localization costs are reduced. Texin 2002 argues that Microsoft used to maintain such a neutral approach to all Spanish-speaking countries in Latin America, disregarding all varieties in one move. This is contradicted by Microsoft's Garrett McGowan and François Liger who state that for the user interface of any .NET application developers should prefer culturesensitive formatting (McGowan no date:10; Liger no date).

'Think global, act local' is not only a motto used often in the localization industry and localization teaching. As the focus lies on the localization part, it is also a mantra a lot of marketeers live by. However, International marketing of products seems to be happening on two extremes. There is a clear use and application of aiming at a specific target locale but the global part evolves around the source product and how to market it as globally as possible. Before devising an advertising campaign around a brand or product, a global marketing strategy needs to be developed first. Even though the term globalization itself may seem familiar to many people, the concept behind it differs a lot depending on the environment of those using the term (Wright 1998). One can paraphrase even that on a cultural level, internationalization is the lead-in activity for globalization as well. Globalization "involves integrating localization throughout a company, after proper internationalization and product design, as well as marketing, sales, and support in the world market" (LISA in Esselink 2000:4). As such, one can view globalization as the sum of at least internationalization and localization. However, within marketing globalization instigates a fundamental dichotomy 'to standardize or localize', whicn in part parallels the domestication discussion in translation studies, even though a standardized global brand would not appeal to a target locale if the product would remain a foreignized element.

It has been argued that globalization constitutes the half of two opposite ends, with standardization being the other side (Medina and Duffy 1998). Companies can opt for a standardization approach, where "the same product is promoted with the same brand name and the same strategy everywhere in the world" or they can chose for adaptation or localization as another alternative "in order ensure the accessibility of a campaign to different cultures" (Maroto 2007). A functionalist and re-creative approach then is the best strategy for the localization of advertisements, whether or not you go from standardized to localized or keep a standardized approach. The purpose of the ad and its general theme need to be trans- 
created properly. By preference, the localization does not happen on the word level. Translating a slogan, which often includes an idiom, a culture-related item or a pun, more often than not produces an advertising blunder.

According to Adab 2000, translation can be produced according to two principles: globalization, "where a text adopts the lowest common denominators (basic values) for product promotion" and localization, "which is less cost-effective, since it involves adaptation of the ST based on culture and language specific mechanisms". She adds an "optimum compromise" to this: glocalization, which is "the production of a globally relevant ST, based on a message that will have similar impacts across different cultural contexts. Such messages will require minimum adaptation, mainly at the level of style and use of language, to be relevant for any single target community" (Adab 2000:224). Glocalization is indeed a reasonably new concept to denote a balance between globalization and localization and as such a saviour for many companies as they no longer have to opt for one way or the other. In essence, however, glocalization constitutes a break with the territorialized nature of localization and creates the opportunity for the global market to be approached in a more deterritorialized way. This allows for a shift, breaking away from the local nation or regional entity and moving towards trans-cultural groupings of target audiences. This is exactly what Smeets 2008 says: "whereas in the past nationalities and their cultural contexts would make out the differentiation, today I would focus on the 'cultural tribes', communities which are all over the world and share some key interests." As an example, Smeets focuses on "the older generation in the 'greying' Europe. For this target audience, the old virtues and cultural differences may be very important." (Smeets 2008).

\section{Localization as a business model}

Even though advertising by nature is a one-way communication only, one can argue that the perceived target audience in its entirety influences that message when localization is involved. Goddard 1998 argues that marketing through advertisements in effect forms a specific discourse that not only reflects our cultural values, but that also contributes a lot on how identities are constructed. As such the perception of identity-building values and cultural references form a 'backbook of innate guidelines' advertisers cannot live without. When a global brand is marketed with hardly any room for local variation, the common value for the target market is very general and cultural perceptions aimed at highly generalized. With a more customized or segmented target market, the local requirements, as steered by its assembled cultural values, connotations and denotations, shape that message in a distinct but distant and passive way.

In marketing, companies approach their own corporate identities along their different advertising needs and the way they envisage their products, the world and the various 
possible locales. Wind et al. 1973 distinguish between four types of companies and respective attitudes: ethnocentric (home country orientation), polycentric (host country orientation), regiocentric (a regional orientation) and geocentric (a global orientation). This categorization is also known as the EPRG model. "These attitudes are assumed to reflect the goals and philosophies of the company with respect to international operations and lead to different marketing strategies and planning procedures" (Wind et al. 1973:14). Companies that use their home base and their own product as the focus of attention, do not specifically look for added values in foreign markets and issue ethnocentric campaigns that on the whole are monotonously standardized. The opposite of these domestic companies are multinational companies, whose polycentric orientation allows for the local subsidiary to develop its own marketing strategy. Advertising is unilaterally decided. In-between these two extremes are companies that view markets as regions (Scandinavia, the British Isles, the Low Countries, the $\mathrm{EU}$ as a whole ...). The more diverse the region, the more countries and cultures it comprises and the more focus lies on images only as language becomes either redundant or limited to a lingua franca. ${ }^{5}$ Geocentric companies on the other hand combine elements of the ethnocentric and polycentric ones: they would orientate the company's marketing towards the entire world and see the globe as one big potential market, but they also develop an integrated marketing strategy around their product(s). Similarities and differences in markets are recognized and local requirements for advertising taken in. Bennett et al 2003 acknowledge that many companies try and keep a standardized tone to their marketing, but also try and maximize the effect of local advertising, effectively providing an integrated communication approach, also known as a marketing mix. However, multinational companies can become so successful, or some of their products in particular, that the brand name becomes a common name. Famous examples include standardized adverting involving globally known brands and their mottos, like 'Always Coca Cola' or 'Just do it'.

\section{Case: Studio 100 and Mega Mindy}

Studio 100 is a Belgian company that produces successful children's television series. Built in 1996 around the local success of a series about a guy and his talking dog ("Samson en Gert"), the company has become the major player in its field in Belgium with a turnover of about 75 million $€$ in 2006, over 300 employees, three theme parks, continuous on the road shows, several music bands and various other successful series. According to Jo Daris, the director of International Affairs, "there is no rocket science to try and localize children's television. Studio 100 distinguishes between pre-school age, up to about seven, and school children, eight to twelve year olds." For the pre-school age, any series would evolve around the same core elements and themes, no matter what costume characters are put in: slapstick elements, one dimensional characters, recognisable situations and storylines, catch phrases, gimmicks and humour. As such, pre-school series only need localizing on one level, which is to mirror the series as much as possible to the business plan aiming at the specific local audience. 
After a major success with a series in the Netherlands (a nearly entirely Dutch team, with final control still in the hands of the Belgian creative director), the company is trying to to approach the British market with Mega Mindy, another hugely successful series, about a low key police woman who when changing into her alter ego becomes a major crime fighter. Studio 100 has localized its pitching leaflets: the UK version has the company information on the first page, whereas this would appear on the last page otherwise. The sections Summary, Back Story and Episode Structuring have been rewritten and focus has shifted to introducing the characters and the gadgets used so far; the latter not surprising given the British tradition of Bond gadgets and Daleks.

\section{Cultural models: quantifiable analyses and tickable boxes}

"At 22, I would have said local stereotypes are in the minds of the persons using it, but after 15 years in B2B and media, I must say many stereotypes prove to be spot on. How frustrating that might be. Of course I'm generalising again."

Goukens 2008

In the light of the discussion of standardization or localization in marketing a product to a specific target audience, keeping the global brand or adapting it culturally, a contested issue appears: how to define and if possible quantify culture? In marketing across cultures, the issue of what actually constitutes a culture persist, especially as the overall "notion of a culture as the essentialized way of life of a people, and generally linked to a geopolitical territory, continues" (Cronin 2006:46). The main purpose of defining what actually constitutes a culture, is the ambition to apply that definition in a cultural model, implement it in a marketing strategy and make cultural sensitivities box tickable. One of the most frequently used cultural models in all this is the work by Geert Hofstede, who wrote on both national and organizational cultures ${ }^{1}$. Working at IBM as a psychologist in the late 1960 s and early 1970s, Geert Hofstede was allowed to access culturally relevant data, 'employee value scores', of several thousands of employees of the same large multinational corporation, IBM. He sampled data from people originating from no less than nearly a hundred different countries and developed a cultural model that initially comprised four dimensions, adding a fifth along the way. The cultural dimensions of Hofstede form one approach to culture, but in the past years have been frequently used in marketing strategies, especially in campaigns involving creation or localization of web pages. The Hofstede dimensions have been applied by Marcus and Gould 2001 on web design and interface structure and elements.

A first dimension, power distance, positions countries on an axis, the power distance index (PDI), where inequality is defined not from above, but from below: "the extent to which the less powerful members of organizations and institutions (like the family) accept and

\footnotetext{
${ }^{1}$ Other cultural models are by Hall, Katan, Trompenaars, Schwartz and Gray.
} 
expect that power is distributed unequally" (Hofstede.com). In Asia, China has a higher power distance index than Japan. Within Europe, Turkey has a high PDI, compared to any of the Scandinavian countries. Marcus and Gould 2001 believe that a high PDI will be reflected in the interface of a web page. An Asian website, compared to a Western European, would contain more presence of official logos or seals, structure and symmetry and prefer pictures of buildings rather than people. A second Hofstede dimension positions individualism (IDV) against collectivism. Clearly, individual societies carry much looser ties between individuals than collectivist societies. In their web design guidelines, Marcus and Gould 2001 use the IDV dimension for images of success versus achievement of social-political agendas, youth and action versus aged and wise and a sense of innovation and uniqueness versus a sense of tradition and history (2001:12). "Another fundamental issue for any society is the distribution of roles between the genders" (Hofstede.com), reflected in the masculinity (MAS) versus femininity dimension. For web page design, Marcus and Gould 2001 believe that this is reflected by images that stress traditional gender distinctions (or not) and by navigation that is oriented to exploration and control. More feminine societies prefer web pages with focus on cooperation, more free navigation and more visual variation. The fourth cultural dimension Hofstede designed is the Uncertainty Avoidance Index (UAI): to what extent do members of a specific culture feel comfortable, or not, when they find themselves in a novel, surprising or unknown situation? Societies with a high UAI tend to avoid uncertainty by a issuing many laws and by having many rules, written or not. According to Marcus and Gould 2001, cultures with a high UAI would expect simplicity from a web page and more than one navigation possibility. Among western countries hardly anyone scores higher in UAI than Belgium, maybe because of their troubled past and continuous complex political issues. The clarity and various options to navigate through a Belgian web site (often three layers) would be in stark contrast with sites of English, French or Dutch origin, which often only have one layer of navigation (beyond the sitemap). After further research, Hofstede added a fifth dimension, the long-term orientation (LTO) versus short-term orientation. It has been argued that this fifth dimension is one of the keys to understand Asian cultures as the long-term orientation there seems to have been influenced by Confucian philosophy (Marcus and Gould 2001:22). Societies with a high LTO would in general focus on practice and patience in achieving results, whereas those with a low LTO would focus on truth and the achievement of goals. An archetypal example of low LTO would be any corporate web site reflecting the German business approach, matched by the cultural Grundlichkeit.

Not only Hofstede himself, but many scholars after him, have stressed that within any cultural framework relativism is necessary, which seems nothing short of an understatement. For starters, Hofstede has been ranking countries along these dimensions, effectively making countries synonymous to cultures, which will upset some people. Surely, Basque, Asturian and Catalan cultures prefer to retain a more independent stanza within Spain. The same goes for countries that officially comprising of several different cultural communities like Belgium, Canada, Switzerland... It is difficult to sustain the image that cultures are bounded, not able to 
evolve, especially "in a world of extensive flows of images, information, people and commodities" (Cronin 2006:47). Linking to Marcus and Gould, a clear web site example is the Toyota web site for Belgium. Even though the Dutch (for Flanders) and French (for Wallonia) versions overlap a lot, there are also differences. Strangely enough those differences become similarities if one compares the Toyota site aiming at the Flemish locale with the Dutch Toyota site and Toyota Wallonia with Toyota France. There are even slight differences in colour use. The same considerations go for advertising beyond web pages.

The advertising and success of a product "will be subject to both cultural and socioeconomic constraints, hence the need to take into account the cultural specificity of each context when designing a marketing strategy ... taking into account not only discourse features, but also visual elements and semiotic functions." (Milan-Varela 2004: 245) Take for instance the advertising of food and how any local appropriation would be reflected in small, but important details, usually non-linguistic. Advertising a cheese throughout Europe would not be easy. Not many brands stand out when it comes to cheese, but types of cheese would (a Camembert, a Brie, an Edammer...). A cheese advert most likely focuses on connotation and denotation; aiming for instance at the social factor (people eat cheese together). However, this image already differs within geographically closely related nations. In France, one would not even remotely think about having cheese and beer in the same commercial, whereas this would not be uncommon in Belgium, where cheese can even be a main course (a table full of cheese, literally a kaastafel). There might even be some mustard accompanying the cheese, which seems very strange to British people as they all know biscuits come along with cheese. What a strange habit to kill off the taste of cheese with mustard. But then again, Belgians also eat horse meat, which would bring down the shivers upon many British people.

\section{Conclusion}

Localization is reasonably well-established as a practical field of multilingual projects involving complex files or software applications. Localization happens on various levels, a linguistic, techn(olog)ical and cultural level. However, localization is also a business model, aiming at selling a product customized to a target locale. As such localization not only becomes part of a marketing strategy and its subsequent advertising, in the world of marketing mixes, localization also becomes the pendant of standardization, Focusing in a marketing campaign on more global or local target audiences, allowing for respectively more or less standardization is a major issue in advertising. This, in part, is overcome by the recent development that marketeers no longer view their target markets along the boundaries of nations or countries, but as global scapes, where cross-cultural, cross-national groups share similar interests. Nevertheless, the advertising success of a product is dependent on cultural sensitivities and despite a lot of criticism cultural models such as Hofstede's five cultural dimensions allow for a tangible grip on cultural sensitivities to be used by marketeers and localizers alike. 


\section{Biography}

Christophe Declercq (1971) graduated as a translator at Lessius, Antwerp. After positions at Lessius, Blondé, Decathlon and Yamagata Europe, he became a lecturer first at Imperial College London and later also at HIVT, University College Antwerp. He has been a visiting lecturer at Lille LEAIII, Lessius, Middlesex University, Metropolitan University and has spoken at EAFT, NL-Term, TAMA, LISA, 'Translation and Meaning' and EST. He published in a.o.

Language International, Language and Documentation and Translation Ireland. He works as a freelance translator, a.o. for Golazo Sports Management, and works closely with SDL and ITR. He is working on a PhD on 'Belgian Refugees in Britain during the Great War'.

List of names and subjects by which the contribution should be indexed

Advertising

Culture

Esselink

Globalization

Hofstede

Internationalization

LISA

Localization

Marcus and Gould

Marketing

Maroto

Standardization

Translation 


\section{References}

\section{Books}

Adab, B. and C. Valdés (eds) (2004) 'Key Debates in the Translation of Advertising Material'. The Translator 10:2. Manchester: St Jerome Publishing.

Bennet, R. , J. Blythe and H. Alder (2003) International Marketing: Strategy Planning, Market Entry \& Implementation. London: Kogan Page.

Blois, K. (2000) The Oxford Textbook of Marketing. Oxford: Oxford University Press.

Branston, G and R. Stafford (1996) The Media Students' Book. London: Routledge

Connor, U., E. Nagelhout and W.V. Rozycki (2008) Contrastive Rhetoric: reaching to intercultural rhetoric. Amsterdam: John Benjamins Publishing Company.

Cook, G. (1992) The Discourse of Advertising. London: Routledge.

Cronin, M. (2003) Translation and Globalization. London: Routledge

Cronin, M.(2006) Translation and Identity. London: Routledge.

Dalton, M. D., C. Ernst, J. Deal, and J. Leslie (2002). Success for the New Global Manager: How to Work Across Distances, Countries, and Cultures. San Francisco: Jossey-Bass Publishers.

De Mooij, M. (2005) Global Marketing and Advertising, Understanding Cultural Paradoxes.

Thousand Oaks: Sage Publications

De Palma, D.A. (2002) Business Without Borders: A Strategic Guide to Global Marketing. New York: Wiley and Sons

Esselink, B. (2000) A Practical Guide to Localization. Amsterdam/Philadelphia: John Benjamins Publishing.

Goddard, A. (2002) The Language of Advertising: Written Texts. London: Routledge.

Hall, E. T. (1981) Beyond Culture. New York: Doubleday.

Hampden-Turner, C. and A. Trompenaars (2000). Building Cross-Cultural Competence: How to Create Wealth from Conflicting Values. New Haven: Yale University Press.

Hatim, B. (1997) Communication Across Cultures. Exeter : University of Exeter Press.

Hatim, B. and I. Mason (1997) The Translator as Communicator. London: Routledge.

Hermans, T. (2002). Crosscultural Transgression. Manchester: St Jerome Publishing.

Hermans, T. (ed.) (2006) Translating Others. Manchester: St Jerome Publishing

Hofstede, G. (2003) Culture's Consequences: Comparing Values, Behaviours, Institutions, and Organizations Across Nations. London: Sage Publications.

Hofstede, G. and G.J. Hofstede (2005) Cultures and Organizations: software of the mind. New York: McGraw-Hill

Holliday, A., M. Hyde and J. Kullman (2004) Intercultural Communication. London: Routledge. House, R. J. et al. (eds) (2003) Culture, Leadership, and Organizations: The GLOBE Study of 62 Societies. Thousand Oaks: Sage.

Katan, D. (1999) Translating Cultures, an Introduction for Translators, Interpreters and Mediators. Manchester: St Jerome Publishing 
Kenny, D. (1998) Equivalence. In: Mona Baker and Kirsten Malmkjaer (eds.) The Routledge Encyclopedia of Translation Studies. London: Routledge.

Kotler, P. et al. (2005) Principles of Marketing. Harlow: Pearson Education.

Malmkjaer, K. (2005) Linguistics and the Language of Translation. Edinburgh:

Edinburgh:University Press.

Marquardt, M. J., and L. Horvath (2001). Global Teams: How Top Multinationals Span Boundaries and Cultures With High-Speed Teamwork. Palo Alto: Davies-Black Publishing.

Martin, J. N. and T. K. Nakayama (2005). Experiencing Intercultural Communication: An Introduction. Boston: McGraw-Hill.

Peterson, L.K. and C. D. Cullen (2000) Global Graphics: Color. Designing with Color for an International Market.

Ricks, D.A. (2006) Blunders in International Business. Malden: Blackwell Publishing.

Scollon, R. and S. W. Scollon (1995) Intercultural Communication. Oxford: Blackwell Publishers.

Shuttleworth, M. and M. Cowie (1997) Dictionary of Translation Studies. Manchester: John

Benjamins Publishing Company.

Smith-Ferrier, G. (2006) .NET Internationalization: The Developer's Guide to Building Global Windows and Web Applications. Boston: Addison-Wesley Professional

Sprung, R. (2000) Translating Into Success. Cutting-edge strategies for going multilingual in a global age. Amsterdam: John Benjamins.

Trompenaars, F. and C. Hampden-Turner (1998). Riding the Waves of Culture: Understanding Cultural Diversity in Business. New York: McGraw Hill.

Usunier, J.-C. \& J. A. (2005) Marketing across cultures. New Jersey: Prentice Hall

Vestergaard, T and K Schroder (1985) The Language of Advertising. Oxford: Blackwell

Williamson, J. (2005) Decoding Advertisements: Ideology and Meaning in Advertising. London: Marion Boyars Publishing.

\section{Articles}

Adab, B. (2000) 'Towards a More Systematic Approach to the Translation of Advertising Texts'. In: Beeby, A. D. Ensinger and M. Presas (eds.) (2000) Investigating Translation. Selected Papers from the $4^{\text {th }}$ International Congres on Translation, Barcelona.

Amsterdam/Philadelphia: John Benjamins. 223-234

Cyr, D. and H. Trevor-Smith (2004) 'Localization of Web Design: An Empirical Comparison of German, Japanese, and U.S. Website Characteristics. In: Journal of the American Society for Information Science and Technology 55:13. New York: John Wiley and sons. 1199-1208

Declercq, C. (2006) 'Tomorrow's Translation Studies Today: Some Considerations'. In: John Kearns (ed.) Translation Ireland 17:1, New Vistas in Translator and Interpreter Training.

Trauben. 121-133

Declercq, C. (2007) 'Translating Colours'. In: Translation and Meaning, part 7. Maastricht: Universitaire Pers Maastricht. 429-438 
Dixon, J. S. (2004) 'Translation, culture and communication'. In: Kittel et al. (eds.) Übersetzung /Translation / Traduction. Berlin: Walter De Gruyter. 11-23

House, J. (2004) 'Culture-Specific Elements in Translation'. In: Kittel et al. (eds.) Übersetzung / Translation / Traduction. Berlin: Walter De Gruyter. 494-505

McSweeney, B. (2002) 'Hofstede's Model of National Cultural Differences and Their Consequences'. In: Human Relations, 55:1. London: SAGE Publications. 89-118

Medina, J.F. and M.F. Duffy (1998) 'Standardization vs. Globalization: a new perspective of brand strategies'. In: Journal of Product and Brand Management 7:3. Bingley: Emerald Group Publishing. 223-243

Melewar, T.C. and J. Saunders (1999) 'International Corporate Visual Identity: Standardization or Localization? In: Journal of International Business Studies 30:3. Palgrave Macmillan Journals.

Millán Varela, C. (2004) 'Exploring Advertising in a Global Context: Food for Thought'. In: The Translator 10:2. Manchester: St Jerome Publishing.

Piotrowska, M. (2006) Cultural Transposition in Strategic Planning. In: John Kearns (ed.)

Translation Ireland 17:1, New Vistas in Translator and Interpreter Training. Trauben. 109-120

Ramarapu, S. and J. E. Timmerman (1999), 'Choosing Between Globalization and Localization As a Strategic Thrust for Your International Marketing Effort'. In: Journal of Marketing Theory \& Practice 7:2. Statesboro: Georgia University. 97-106

Schäffner, C. (1998) Skopos Theory. In: Mona Baker and Kirsten Malmkjaer (eds.) The Routledge Encyclopedia of Translation Studies. London: Routledge.

Séguinot, C. (1995) Translation and Advertising: Going Global. In: Christina Schäffner and Helen Kelly-Holmes (eds) Cultural Functions of Translation, Clevedon: Multilingual Matters, 55-71.

Sirisagu K. (2000) 'Global Advertising: Practices A Comparative Study'. In: Journal of Global Marketing 14:3. Philadelphia: Haworth Press. 77-97

Snell-Hornby, M. (1999) 'The Ultimate Comfort: Word, Text and the Translation of Tourist Brochures'. In: Anderman, G.M., M. Rogers (eds) Word, Text, Translation: liber amicorum for Peter Newmark. Clevedon: Multilingual Matters. 95-103

Venuti, L. (2000) 'Translation, Community, Utopia'. In: Lawrence Venuti (ed.) The Translation Reader. London: Routledge.

Verschueren, J. (2007) The Interventionist Role of (Re)Contextualization in Translation. In: Munday, J. (ed.) Translation as Intervention. New York: Continuum.

Wind, Y., S. P. Douglas and H. V. Perlmutter (1973) 'Guidelines for Developing International Marketing Strategies'. In: Journal of Marketing, 37:2. Birmingham: American Marketing Association. 14-23 


\section{Dissertations, student papers, working papers and reports}

Barraclough, C. (2007) Translation As Mediation: An Ethics of the Involved. London: Imperial College London (unpublished MSc dissertation)

Bielsa, E. (2005) Globalisation as Translation: An Approximation to the Key but Invisible Role of Translation in Globalisation. Warwick University/ ESRC Centre for the Study of Globalisation and Regionalisation Working Papers, 163/05. Available from

www.trudeaufoundation.ca/libraryservices/download-nocache/Library/ac/centre 1/global 3 (last accessed 30/05/2008)

Jagne, J., et al. (2004) Cross-cultural Interface Design Strategy. London: Middlesex University (technical report) Available from www.dcs.qmw.ac.uk/ pc/publications/2004/IDC-TR-2004006.pdf (last accessed 31/05/08)

Jurisic, H. (1998) Translation in Advertising: A Focus on the Persuasive Function. Toronto: York University (dissertation published online) available at

http://www.collectionscanada.gc.ca/obj/s4/f2/dsk1/tape11/PQDD 0019/MQ48198.pdf (last accessed 03/06/08)

Magiati, N. (2005) Intercultural Communication and International Marketing: Corporate Advertising. Universität Heidelberg: Heidelberg (published thesis)

Maroto, J. (2005) Cross-cultural Digital Marketing in the Age of Globalization. Tarragona: Universitat Rovira i Virgili. (unpublished dissertation).

McKeown, R. (1998) 'Le Parfum de Washing Up', A Semiotic Analysis of Two Ads for Persil Liquid. (student paper published online) Available from www.aber.ac.uk/media/Students/rum9501.html (last accessed 30/05/08)

Solomonides, V. (2007) Katan's logical levels of culture and their relevance for translation. London: Imperial College London (unpublished essay).

\section{Online material}

Bezuidenhout, I. (1998) Discursive-Semiotic Approach to Translating Cultural Aspects in Persuasive Advertisements. Available from http://ilze.org/semio/index.htm (last accessed 26/11/07)

Epica d'Or 2002, available from www.epicaawards.com/pages/pastresults2002 epicador.html (last accessed 31/05/08) GALA (2008) Language Technology and Services Directory. Available from www.galaglobal.org/vendor-database.html (last accessed 31/05/08) Globalization blog: Analysis and Advice on Content Globalization \& Localization Issues. Available from http://gilbane.com/blog (last accessed 31/05/08)

Guidiere, M. (2001) Translation Practices in International Advertising. In: Translation Journal, Available from http://accurapid.com/journal/15advert.htm (last accessed 31/05/08) 
Guidiere, M. (no date) The Translation of Advertisements: from Adaptation to Localization. Available from www.translationdirectory.com/article60.htm (last accessed 31/05/08)

Hofstede, G. (no date) Geert Hofstede's Homepage, available from

http://feweb.uvt.nl/center/hofstede/index.htm (last accessed 31/05/08)

Hofstede, G. (no date) Geert-Hofstede.com, available from www.geert-hofstede.com (last accessed 31/05/08)

Husband, G. (no date) 'Is Thinking Global Killing Local? Successfully Integrating Local Insights into Global Strategy'. Available from www.translationdirectory.com/article625.htm (last accessed 31/05/08)

Icom Europe (no date) Launch of Peugeot 207. Available from

http://www.icomagencies.eu/cases/Sweden case NI.pdf (last accessed 31/05/08)

Kammeyer, M. (2001) The Other Customer Barrier: cultural research avoids business blunders. International Trade Administration. Available at www.ita.doc.gov/exportamerica/Volume\%202/April\%202001/im CulturalEti.pdf (last accessed 31/05/08)

Liger, F. (no date) Globalization Support in Microsoft .NET Framework. Available from download.microsoft.com/download/8/f/5/8f5d1ac4-46e3-4afb-b234-2cf2386d0e0e/20dotNetFr-Globaliz_c.ppt (last accessed 31/05/08)

LISA (1998) LEIT Phase I Final Report. http://leit.lisa.org/pubs/public.pdf (last accessed $31 / 05 / 08)$

LISA (2008) LISA Members. Available from www.lisa.org/LISA-Members.74.0.html (last accessed 31/05/08)

LISA (2005) Lisa Forum Cairo: Localization: Perspectives From the Middle East and Africa. Available at www.lisa.org/events/2005cairo/ (last accessed 30/05/08)

Marcus, A. (2001) 'Cross-Cultural User-Interface Design'. In: Proceedings of Human-Computer Interface conference. Smith, M. J. and Salvendy, G. (eds.). 502-505. Also available from www.amanda.com/resources/HCII01/HCII01 PanXC Marcus 160401.pdf (last accessed 31/05/08)

Marcus, A. (2005) Cross-Cultural User-Experience Design. Available from www.engr.udayton.edu/faculty/wsmari/cts06/CTS2006\%20Tutorial\%20III\%20-\%20Notes.pdf (last accessed 31/05/08)

Marcus, A. and E.W. Gould (2001) Cultural Dimensions and Web Design. Available from www.amanda.com/resources/hfweb2000/AMA CultDim.pdf (last accessed 31/05/08) MarketingProfs Knowledge Exchange (2004) Standardization v. Localization in Advertising. Question and Answer forum, available from www.marketingprofs.com/ea/qst question.asp?qstID=2896 (last accessed 31/05/08) Maroto, J. (2003) 'Challenging Times for International Advertising Campaigns'. In: The Globalization insider. 12:2. Available from isg.urv.es/library/papers/MarotoChallenging.pdf (last accessed 31/05/08)

Maroto, J. (2007) 'Multiple Dimensions of international advertising, an analysis of the praxis in global marketing industry from a translation studies perspective'. In: Conference Proceedings 
of MuTra 2007 - LSP Translation Scenarios. Available from

www.euroconferences.info/proceedings/2007 Proceedings/2007 Maroto Jesus.pdf (last accessed 31/05/08)

Maroto, J. (2007) 'A research model for the localization of advertising'. Abstract available from http://isg.urv.es/seminars/2006 new research/Abstracts.pdf (last accessed 31/05/08)

Maroto, J. and M. De Bortoli (2001) Translating colours in web site localization. Available from www.geocities.com/spanishlocalizer/files/colors.pdf (last accessed 31/05/08)

Maroto, J. and M. de Bortoli (2001) Web Site Localization. In: Proceedings of the European Languages and the Implementation of Communication and Information Technologies (Elicit) conference. Paisley: University of Paisley. Available from

http://wise.vub.ac.be/members/mushtaha/PhD/phd-activity/weblocal.pdf (last accessed 31/05/08)

Maynard, M.L. (2003) ‘From Global to Glocal: How Gilette's SensorExcel Accomodates to Japan'. In: Keio Communication Review 25. Available from

www.mediacom.keio.ac.jp/publication/pdf2003/review25/5.pdf (last accessed 31/05/08)

McGowan, G. (no date) Microsoft . NET Development Platform Internationalization.

Powerpoint presentation Available from

http://download.microsoft.com/download/1/c/f/1cfa8051-c1e1-447b-8476-

f8be6c14b1ef/21-dotNet i18n c.ppt\#1 (last accessed 30/05/08)

Microsoft (2001). Localization Guidelines for your User Interface. Available from msdn.microsoft.com/en-us/library/aa163857(office.10).aspx (last accessed 31/05/08)

Morkman (2008) Available from www.morkman.se, (last accessed 31/05/08)

Morris, P. K. and Lee, S. (2005) 'Culture and Advertising: An Empirical Study of Cultural

Dimensions on the Characteristics of Advertisements'. Paper presented at the annual meeting of the International Communication Association, New York City. Available from

www.allacademic.com/meta/p12814 index.html (last accessed 31/05/08)

Murphy, J. and A. Scharl (2007) 'An Investigation of Global Versus Local Online Branding'. In: International Marketing Review 24:3. Emerald Group Publishing Limited. 297-312. Available from web.biz.uwa.edu.au/staff/jmurphy/global_local_branding.pdf (last accessed 31/05/06)

Noble, G. and M. Camit (2005) Social marketing communication in a multicultural environment: Practical issues and theoretical contributions from cross-cultural marketing.

Available from

praxis.massey.ac.nz/fileadmin/Praxis/Files/Journal_Files/Social_Marketing/Noble_Camit.pdf (last accessed 31/05/08)

Plan8 (2008) Selected. www.plan8.se/selected.php (last accessed 21/05/08)

Pym, A. (2005) Localization: On its nature, virtues and dangers. Available from

www.tinet.org/ apym/on-line/translation/Localization bergen.doc (last accessed 31/05/08)

Sells, P. and S. Gonzalez (2002) The Language of Advertising. Stanford University.

www.stanford.edu/class/linguist34/index.htm (last accessed 26/11/07)

Smith, A., T. French and K. Gunter (2003) 'The Role of Cultural Theories Within International Usability'. In: Rauterberg et al. (eds.) Interact 03: Human-Computer Interaction. Available 
from:

www.idemployee.id.tue.nl/g.w.m.rauterberg/conferences/INTERACT2003/INTERACT2003p1097.pdf (last accessed 21/05/08)

Texin, T. (2002) Microsoft's approach to "Universal" or "Neutral" Spanish. Available from www.i18nguy.com/I10n/MS LA Spanish.html (last accessed 30/05/2008)

Texin, T. (2006) Internationalization (I18n), Localization (L10n), Globalization (G11n), Guidelines, Checklists, and Resources. Available from www.i18nguy.com/guidelines.html (last accessed 30/05/2008)

Usunier J-C. et al. (2007) 'The standardization of international advertising: an analytic review'. In : 36th European Marketing Academy Conference. Available from

www.hec.unil.ch/cms irm/WP0708.pdf (last accessed 31/05/08)

Van Gelder, S. (2002) General Strategies for Global Brands. Amsterdam: Brand Meta. Also available from www.placebrands.net/ files/General Strategies for Global Brands.pdf (last accessed 30/05/2008)

Wiersema, N. (2004) 'Globalization and Translation : a discussion of the effect of globalisation on today's translation'. In: Translation Journal 8:1, Available from http://accurapid.com/journal/27liter.htm

Wright, S. E. (1998) 'What are We Talking About? Key Terms in the Localization Industry.' In: LISA Globalization Insider 1998:3. Available at http://www.lisa.org/globalizationinsider/1998/07/what are we tal.html (last accessed 30/05/08) 


\section{Personal and email conversation}

Benoit, G. (2008), Yamagata Europe, Ghent, Belgium, email exchange

Daris, J. (2007) Studio 100, Schelle, Belgium, email exchange and personal conversations

Goukens, L. (2008), Crux Editions Belgium, email exchange

Lawrence, D. (2008) LISA, Romainmôtier, Switzerland, email exchange

Maroto, J. (2008) Global Propaganda, Granada, Spain, email exchanges

Smeets, P. (2008), Interstate Advertising, Düsseldorf, Germany, email exchange

\footnotetext{
${ }^{1}$ Four of these concepts are also referred to as GILT: globalization, internationlization, localization and translation. These concepts sometimes are abbreviated with the number of characters between the first and last letter as a number between those two letters. GILT then includes g11n, i18n, I10n and t9n.

${ }^{2}$ LISA, established in 1990, anticipated the need for localization industry standards and over the years became a key player in the field. Current LISA members include Adobe Systems, Cisco Systems, Directorate-General for Translation of the European Commission, Hewlett-Packard, Lessius Hogeschool, LionBridge, Nokia Corporation, SDL International and World Bank Group. ${ }^{3}$ Another major organization in the field of localization is GALA, The Globalization and Localization Association. Like LISA, GALA also offers consultancy services and organizes events for the localization industry. Their website is one of the convergence points of localization services with over 200 companies in the category 'software localization' alone. Members include Argos, Atril, Celer Solutions, Cross Language, LionBridge, MultiCorpora and Yamagata Europe. Other players in the field are The Localization Institute, which offers training and certification, Localization World, which organizes conferences and offers a web-based networking service, TiLP, the Institute of Localization Professionals, which also offers certification, and the Localization Research Centre (LRC) in Limerick. ${ }^{4}$ All these commercials can be retrieved via YouTube, but because of the rather fleeting character of these contents, no links are provided.

${ }^{5}$ This visual aspect of regiocentric advertising breaks away from Sapir-Whorf's responsibility of the translator/localizer to acknowledge the linguistic relativity which stipulates that people need natural language to understand the world.
} 